\title{
Direct economic impact of tourism on World Heritage Cities: An approach to measurement in emerging destinations
}

\author{
Pablo Juan Cárdenas-García, Juan Ignacio Pulido-Fernández, \\ Ana Belén Mudarra Fernández \\ e-mail: pcgarcia@ujaen.es, jipulido@ujaen.es, abmf0003@red.ujaen.es \\ Laboratory of Analysis and Innovation in Tourism (LAInnTUR), \\ Department of Economics, University of Jaén, Spain \\ Cárdenas-García, P. J., Pulido-Fernández, J. I., \& Mudarra-Fernández, A. B. (2014). Direct economic impact of tourism \\ on World Heritage Cities: An approach to measurement in emerging destinations. Czech Journal of Tourism, 3(2), 91-106. \\ DOI: $10.1515 /$ cjot-2014-0005.
}

\begin{abstract}
In 2013, it had been ten years since the World Heritage designation of Úbeda and Baeza. After this time period, there should have been a change in the image of this tourism destination, which should have been translated, according to the literature, into an increase in tourism, and, consequently, into a greater impact of this activity on the economy of both cities.

The aim of this work is to evaluate whether the designation of Úbeda and Baeza as World Heritage Cities has led to an increase in the economic impact generated by tourism in these destinations. To do this, the evolution of the main tourism variables of these cities over the last decade has been analysed, concluding that, indeed, there has been an increase in the direct economic impact generated by tourism in these cities, which is mainly explained by an increase in average daily expenditure.
\end{abstract}

\section{Keywords}

Tourism, economic impact, tourism expenditure, Úbeda-Baeza (Spain), World Heritage Cities.

JEL classification: C00, L83, Z10 / Accepted: 8 June 2015 


\section{Introduction}

Tourism is an activity that has experienced sustained high rates of economic growth in recent years, as well as it has been presented as a form of development alternative in some areas (Cárdenas, 2012). In this sense, some destinations, such as Cordoba, New Delhi or Ferrara, which are World Heritage Sites, have experienced an increase in their economic activity as a result of a growth in tourist arrivals.

Destinations offer a combination of tourism products that create an integrated experience to tourists. Despite the preconceived notion that a tourism destination must have a specific image, it is more frequently acknowledged that the destination is subjectively perceived by consumers according to their educational level, motivation for the visit or previous experience (Bigné, Andreu, \& Font, 2000). However, each destination has a number of specific features that attract tourists who are interested in their resources, considering as such any element that could motivate tourists to travel to the destination. That is to say, tourism resources are all those goods which, through the activity of humans and the means available to them, enable tourism activity and satisfy the needs of tourism demand (Calderón, 2009).

Knowledge of other cultures is among the different needs of the demand, which has meant that cultural resources are no longer regarded as a simply ornamental. Thus, a cultural resource involves the use of heritage and tourist attractions by means of a series of actions linked to the creation of a tourism product, and to its promotion. In this regard, UNESCO promotes the development of proposals that make the most of the relationship between culture and tourism by creating strategic partnerships to jointly meet development interests through cultural experiences for all humankind.

Moreover, for any tourism destination, it is particularly important to analyse tourist expenditure in its territory, as it is the core around which all economic impacts revolve; generation of income, job creation and tax revenue collection (Cárdenas, 2012; Brida \& Scuderi, 2012); and it is considered, therefore, a fundamental variable in the analysis of the tourism market although its examination is becoming increasingly complex.

Furthermore, over the last few years, the need for identifying the factors determining tourism expenditure has increased due to the fact that tourists have specific characteristics such as age, origin, income level, or occupational status that tend to condition the level of expenditure associated with a certain tourism activity. Thus, the study of the factors explaining such expenditure is essential to guide both the private sector and those responsible for defining tourism policies (King \& Woodside, 2001; Woodside \& Dubelaar, 2002).

Úbeda and Baeza were designated as World Heritage Sites by UNESCO on 3 July 2003, owing to their extensive list of cultural resources. The aim of this research work is to determine whether this event has led to an increase in the economic impact generated by tourism activity. To meet this objective, an approach to this economic impact between 2003 and 2012 has been developed through a survey specifically designed for this purpose, using a sample of 353 respondents and different databases generated by the National Institute of Statistics and the Institute of Statistics and Cartography of Andalusia. 


\section{Theoretical basis}

In recent decades, a number of countries that are committed to tourism has been increasing as a result of the growing social and economic importance of this economic activity as its development enhances the market (both national and local) and may become a key driver of socio-economic development in these regions (Barroso \& Flores, 2006).

However, in order for tourists to decide to travel and stay overnight at a destination, it is necessary that the latter has enough tourist appeal (UNWTO, 1998). To be precise, as Pulido-Fernández (2013) points out, the destination must generate a value to tourists, and this can only be achieved if it is able to contribute to the solution to a problem or satisfy a tourist need.

Furthermore, it should be noted that the total tourist expenditure at the destination, as well as the activities they engage in there, will depend on the characteristics of tourists, and so the analysis of tourist behaviour is a difficult task (Wu, Zhang, \& Fujiwara, 2011). All these factors are closely related propensity to spend of tourists and the image they have of the tourist destination. In addition, total expenditure is also clearly influenced by the length of the stay. In this regard, there are numerous studies carried out by different authors, such as Thrane and Farstad (2011), who include the duration of the trip in the total expenditure regressions in a linear manner, which indicates that each additional night entails a sustained increase in total expenditure; while other authors have stressed that the duration of the trip has no effect on daily expenditure (Fredman, 2008; Kim et al., 2008; Laesser \& Crouch, 2006; Mork \& Iverson, 2000).

However, in deciding to spend more money at the destination, tourists need that the territory offers a number of resources transformed into the products that make that territory a unique place, recognised by tourists and institutions. But, although all instruments are important to customers when they travel to certain tourism destinations, their decision is based on the specific image that they have generated for tourists (Echtner \& Ritchie, 1991).

Destination image is understood as the sum of beliefs, ideas, impressions and expectations that a tourist has about that destination (Crompton, 1979). Other authors consider that the destination image is an overall or total expression which is formed as a result of the evaluation of the individual attributes which may have both cognitive and emotional content (Oxenfeldt, 1974; Dichter, 1985). This conveys the idea that the image of a tourism destination not only focuses on cognitive and emotional images, but on each of the attributes that are part of it, which must be recognised both at individual (i.e. by tourists) and institutional level (i.e. by major international organisations).

In order to project a favourable image as a tourism destination in the case of cultural destinations, these must be associated with strong brand images, among which the designation as World Heritage by the United Nations Organization Educational, Scientific and Cultural Organization (UNESCO) should be highlighted. It must be noted that nowadays there is a high level of information about the different destinations available to tourists. The creation of a brand image therefore becomes particularly important as the increase in tourist flows, and consequently, in tourist revenue for the destination de- 
pends strongly on it. Due to this, great efforts must be made by the different institutions, both public and private, to create a destination image that is strong, consolidated and attractive to tourists (Pulido-Fernández, 2013).

As previously mentioned, UNESCO is an institution that contributes to the creation and/or consolidation in the markets of the image of a tourism destination through its designation as a World Heritage Site and by allowing the use of its logo (Poria et al., 2011).

However, well-known authors, such as Leask (2006), question the above statement and suggest the need to investigate the role that the designation by UNESCO actually plays in relation to values such as the influx of tourists and, therefore, the generation of income in the territory. Other authors have studied aspects such as the monitoring, conservation and restoration of certain territories that had previously been designated as World Heritage Sites, such as Angkor, in Cambodia (Winter, 2007), or Lijiang, in China (Wang, 2007). Among the issues that these authors have considered there is the distinction between the different resources within an area designated as a World Heritage Site. These include such diverse resources as temples (such as the Preah Vihear temple, Angkor) or natural reserves (such as the Iguazu National Park, Argentina). Considering that these resources, which can be cultural or natural, respectively, are the basis of the attractiveness of a place, particular emphasis should be placed on their protection, preservation and conservation.

So far, research has shown that there is a high degree of correlation between cultural memory, personal and social awareness, self-appraisal and offer of different experiences, which all together make up the concept of cultural landscape that is being promoted by UNESCO. This suggests that nature becomes more important in the space-time environment in which heritage and human experience (i.e. practices, traditions and physical-spatial testimonies) operate as an attraction for the knowledge and enjoyment of an experience that is culturally developed in the local context, but valued as part of the global identity of humanity (Venturini, 2010).

In short, cultural experience involves communication between visitors and locals. Therefore, for tourists it is making them appreciate the emotional-sentimental fact of the "discovery" of the wonders of a territory, its people or its traditions; and, for the receiving society it is acquiring a sense of pride for their heritage and history as these are part of their world and of their "experiences" and may lead to a possible desired future, trying that tourists capture this view. Only then, and through the promotion of the tourism destination brand, the territory will be attractive to tourists, tourist flows will increase and, provided that good and attractive tourism products are available, tourist expenditure in the territory will increase too, which will result in a significant economic impact on society, and therefore, in the development of the territory. 


\section{Methodology}

The aim of this study is to assess whether the designation of Úbeda and Baeza as World Heritage Sites by UNESCO has led to an increase in the economic impact generated by tourism. On this basis, the impact generated by this activity between 2003 and 2012 is compared by analysing the expenditure variables that have evolved over the given reference period, which seems to be the main determinants of its evolution. The authors have used this time horizon because it covers a sufficiently long period of time (i.e. ten years), which makes it possible to test the hypothesis suggested in this paper on the impact generated by the designation of Úbeda and Baeza as World Heritage Sites.

\section{Case study}

Úbeda and Baeza are two cities located in the province of Jaen, in the south-east of the Iberian Peninsula (Figure 1), where tourism is one of the main sources of income although there are other activities strongly rooted in this territory, such as olive growing or craft work, which have gained a positive international image that reinforces the tourism image of this tourism destination as a whole.

Figure 1 Location of Úbeda and Baeza

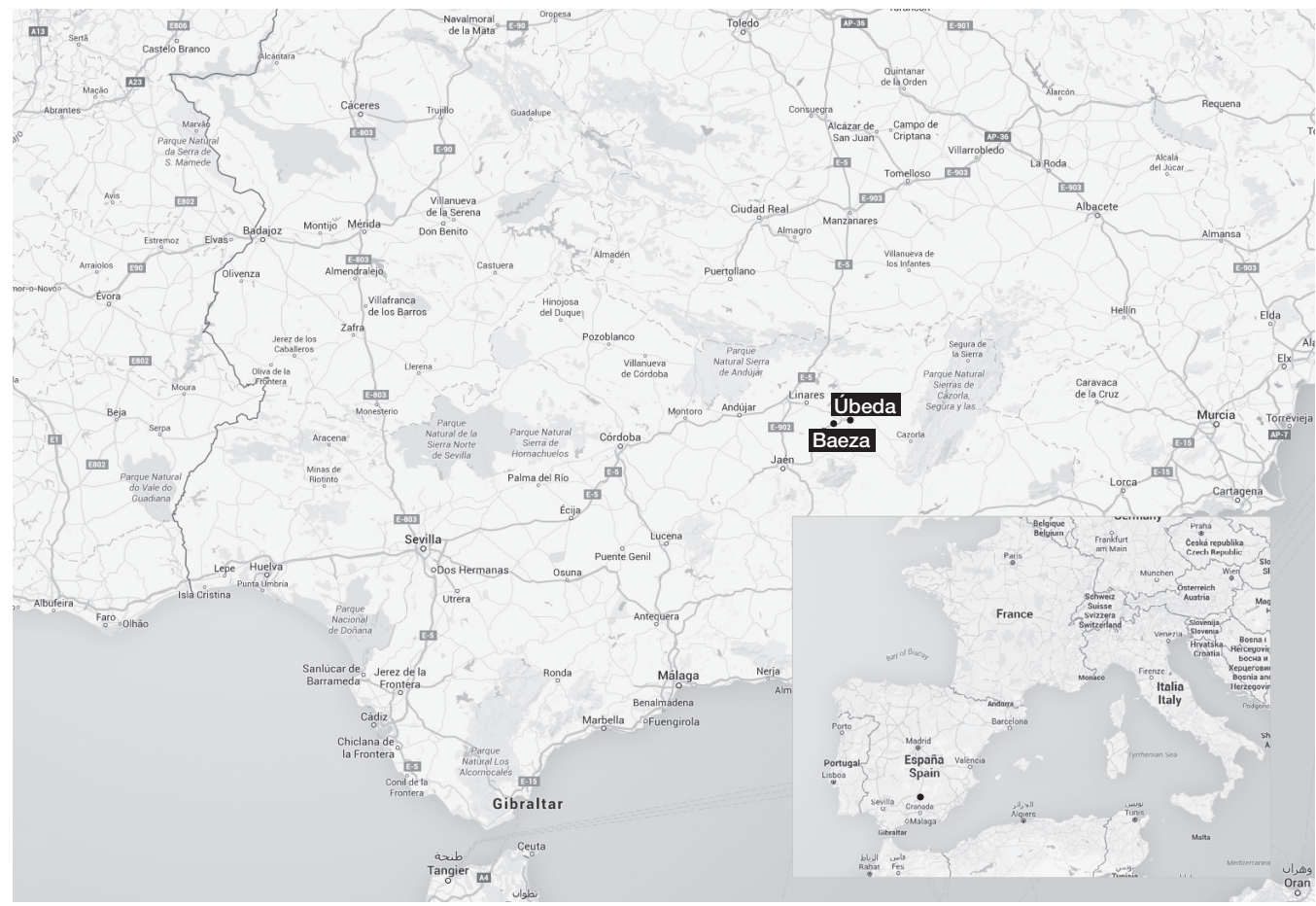

Source: Wikimedia Commons (2014) 
Since the designation of Úbeda and Baeza as World Heritage Sites by UNESCO in 2003 under the title: "Úbeda-Baeza: Urban duality, cultural unity" tourism development was boosted in this territory, and new initiatives, both public and private, emerged to launch and diversify the existing tourism offer.

Nowadays, Úbeda and Baeza comprise a wide range of resources with capacity to meet the expectations of the most demanding tourists, including rich archaeological, cultural, ethnographic and natural heritage. These resources have been enhanced as a result of the implementation of local development projects, both private and public, which have made them more economically and socially profitable. Thus, they have become a key element for the sustainable, tourism, economic and social development of the territory.

Despite this, these two destinations can be considered as emerging destinations since they are still at an early stage of development, having few tourism products, all of which are undergoing a consolidation process, without a strong position in international markets, even in the domestic market. This situation complicates the analysis of the economic impact of tourism in these cities as there is still a significant lack of statistical information, which requires very specific approaches using common secondary sources.

\section{Method of analysis}

In measuring the economic impact generated by tourism in order to ensure the quality of the results, the methods used should meet certain requirements. In this regard, the essential criteria for a study on the economic impact of tourism are: relevance, coverage, efficiency, accuracy and transferability (Frechtling, 1994; Martínez, 2003).

Taking these criteria into consideration, the methodology used in calculating the direct economic impact generated by tourists visiting Úbeda and Baeza is based on the following expression, according to the methodology developed by Pawlowska and Martínez (2009):

\section{DEI: NT x AET}

Where:

DEI: Direct economic impact

NT: Number of tourists

AET: Average expenditure per tourist

This formula requires a series of sequential steps for the estimation of the economic impact of tourism (Stynes, 1999):

1. Estimate the number of tourists in the tourism destination.

2. Estimate the level of tourism expenditure (often in relation to specific market segments) by tourists in the tourism destination. 
Therefore, direct economic impact is calculated as follows:

\section{DEI: NT x ADE x ALS}

Where:

DEI: Direct economic impact

NT: Number of tourists

ADE: Average daily expenditure

ALS: Average length of stay

However, the total economic impact generated by tourism in a destination also includes the indirect economic impact (while tourism enterprises increase the consumption of goods and services to other direct suppliers) and induced economic impact (since part of the rent is aimed at the hands of the resident population which increases the procurement of goods and services in the local economy).

The measurement of these effects is made through the application of multipliers of the matrix of technical coefficients of the Model Input-Output. Therefore, in this paper it has not been possible to measure them since, although in the whole of Spain many tourist data can be found in the tables of input-output, unfortunately, these tables are not available for these two destinations.

Moreover, in calculating the direct economic impact the arithmetic mean has been used. As it can be seen in Figure 6 and 8, the amplitude of the confidence interval obtained for the average expenditure by tourists is very small. Therefore the authors can use this statistics as there is no possibility of distortion in the absence of values ends.

\section{Databases}

According to the methodology previously outlined, it is necessary to calculate the number of tourists visiting a destination, their average daily expenditure in tourism activities and the average length of their stay at the tourism destination.

Thus, given that the analysis performed in this paper examines the direct economic impact of tourists during their stay in Úbeda and Baeza and the results obtained are put into perspective by comparison of the economic impact generated by tourism in Andalusia as a whole. The necessary information has been obtained from different sources (Table 1).

The data are obtained from three different information sources which are complementary. A brief summary of these information sources is presented below:

1. Hotel Occupancy Survey (2003-2012): compiled by the National Institute of Statistics; it presents two kinds of data as it considers the study of tourism from the demand point of view (through travellers, overnight stays and average length of stay, distributed by travellers' country of origin and type of establishments) and from the supply point of view (through the estimated number of open establishments, estimated number of vacancies, occupancy rate and information on employment in this sector, according to type of establishment). 
Table 1 Information sources used

\begin{tabular}{|l|l|}
\hline Úbeda and Baeza & Andalusia \\
\hline Number of tourists & Number of tourists \\
Hotel Occupancy Survey (official) & Andalusian Tourism Situation Survey (official) \\
\hline Average daily expenditure & Average daily expenditure \\
2003: Hotel Occupancy Survey (official) & 2003: Andalusian Tourism Situation Survey (official) \\
2012: Own survey & 2012: Andalusian Tourism Situation Survey (official) \\
\hline Average length of stay & Average length of stay \\
Hotel Occupancy Survey (official) & Andalusian Tourism Situation Survey (official) \\
\hline
\end{tabular}

Source: Authors' own processing

2. Andalusian Tourism Situation Survey (2003-2012): compiled by the Institute of Statistics and Cartography of Andalusia; it is a continuous quarterly survey covering the short-term movements of the variables that it investigates, which is aimed at gaining knowledge about the profile of tourists visiting Andalusia, their level of expenditure and their level of trip satisfaction.

3. Authors' own survey (2012) conducted for this study: due to the paucity of data over the last few years to obtain the average daily expenditure by tourists in Úbeda and Baeza in order to compare it with the same variable in 2003, these data have been collected using a survey designed for this study (Table 2). This survey consists of demographic, economic or psychographic data, both qualitative and quantitative, on tourism demand. For this purpose, 353 tourists visiting Úbeda and/or Baeza -who stayed overnight, at least one night, in one of these cities during the month of September 2013- were surveyed after being informed of the confidential nature of the information supplied; and provided data on the demand, including qualitative aspects that the Hotel Occupancy Survey did not reveal.

In order to guarantee the representativeness of the sample, its random selection has been ensured as well as the chance of all subjects forming the universe to be part of the sample, according to a series of strata. The population under study consists therefore of the tourists (not day trippers) visiting the two aforementioned destinations. The survey was conducted during their stay at the destination and the information was collected at different control points within these destinations using stratified random sampling based on a tourism index published by La Caixa, which measures the importance of tourism activity in different Spanish tourist destinations (La Caixa is a Spanish bank that since 1996 has published a statistical yearbook, which includes, among others, an index that synthesises tourist development in the municipalities of Spain).

Therefore, as it can be seen, to quantify the average daily expenditure, the authors have used two sources of information. However, in order to ensure comparability of tourism expenditure in the two databases used („Hotel Occupancy Survey“ and „Own 
survey“), they have followed in their own survey the same methodology used by the official „Hotel Occupancy Survey“; i.e. the tourism expenditure includes the spendings by tourists in either of these two locations. That is why only the expenditure incurred during the trip is included. Therefore the costs prior to the arrival at destination (for example, it does not include transportation to the destination) are not counted.

Table 2 Basic data of the survey

\begin{tabular}{|l|l|}
\hline Population & Tourists staying overnight in one of the destination cities \\
\hline Scope & Municipalities of Úbeda and Baeza \\
\hline Type of survey & Structured questionnaire completed through a face-to-face interview \\
\hline Sample size & 353 valid surveys \\
\hline Sampling error & $\pm 5,2$ per cent \\
\hline Confidence level & 95 per cent $(p=q=0.50)$ \\
\hline Fieldwork period & September 2013 \\
\hline
\end{tabular}

Source: Authors' own processing

The survey also quantifies the tourism expenditure in the destinations in order to characterize it from the sociodemographic point of view. In this sense, Table 3 provides the main characteristics of the respondents.

Table 3 Composition of the tourists' individual characteristics

\begin{tabular}{|l|l|r|r|}
\hline \multicolumn{2}{|l|}{ Features of tourists } & N & $\%$ \\
\hline \multirow{2}{*}{ Gender } & Males & 187 & 53.0 \\
& Females & 166 & 47.0 \\
\hline \multirow{2}{*}{ Nationality } & Domestic & 297 & 84.1 \\
& Foreign/ international & 56 & 15.9 \\
\hline \multirow{5}{*}{ Age } & $18-30$ & 20 & 5.6 \\
& $31-40$ & 46 & 13.0 \\
& $41-50$ & 51 & 14.5 \\
& $51-80$ & 236 & 66.9 \\
\hline \multirow{3}{*}{ Education Level } & Primary education & 72 & 20.4 \\
& Secondary education & 144 & 40.8 \\
& University education & 137 & 38.8 \\
\hline Total & $<1,500 €$ & 44 & 12.5 \\
& $1,500 €-3,000 €$ & 154 & 43.6 \\
& $>3,000 €$ & 155 & 43.9 \\
\hline
\end{tabular}

Source: Authors' own processing 


\section{Results and Discussion}

The following section provides an approach to the study of the direct economic impact of tourism in Úbeda and Baeza, which was analysed in relation to the Andalusian region as a whole.

It should be remembered, first, as indicated in the "method of analysis" that only those tourists who spent at least one night in the destinations in which the survey was conducted were included. This is due to the fact that these destinations do not charge tourists for admission to many of their cultural sites. Therefore the expenditure by those visitors who do not stay overnight (i.e. they do not spend money on accommodation) is virtually non-existent or very low.

In line with most of the literature review, the visitors who do not stay overnight at least one night were excluded from this study for two main reasons: i) the decisions about tourism expenditure of those visitors who have their place of residence in, or near, the destinations analysed are not comparable to those of the other tourists studied as they could be considered as "captive demand" (Mazon \& Aledo, 2005; Torres, 2003); ii) those who visit the destination for a few hours show a different pattern of expenditure in relation to other goods and services consumed during their holidays (García-Sánchez et al., 2013).

As it can be seen in Table 4, the provinces which attract the greatest number of tourists are Malaga, Granada and Cadiz. This is due to the focus of Andalusia on those tourists seeking sun and sand (as it is the case of Malaga and Cadiz), or on major cultural tourism icons as it is the case of Granada. As far as the average length of the stay is concerned, the highest figures are found in the provinces of Malaga, Almeria and Cadiz. In this case, the three of them are located on the coast. Finally, regarding the average expenditure by tourists, figures indicate that the provinces with a higher level of average expenditure are Sevilla, Cadiz and Jaen.

It is clear why Malaga shows the greatest direct economic impact: it attracts more tourists than any other province, and the number of days that they stay in its territory, that is, tourists' average length of stay, is longer than in the rest of the Autonomous Community.

After analysing the economic impact of tourism in Andalusia in 2003, the results obtained were compared with the data on the economic impact of tourism in Úbeda and Baeza that same year when these cities were designated by UNESCO as World Heritage Sites. To do this, the necessary data for determining the direct economic impact of tourism in Úbeda and Baeza in 2003 were provided in Table 5.

Obviously, the number of tourists visiting Úbeda and Baeza, compared to other provinces of Andalusia, is much lower. Moreover, the average length of their stay is also shorter. However, in contrary to expectations, the average expenditure by tourists in Úbeda and Baeza is in line with the average level of expenditure in all provinces of Andalusia.

But the most important analysis, according to the research hypothesis, is the comparison between the economic impact of tourism in Úbeda and Baeza in 2003 when these cities were designated as World Heritage Sites, and the economic impact of tourism in 
Table 4 Direct economic impact of tourism in Andalusia (2003)

\begin{tabular}{|l|c|c|c|r|r|}
\hline \multirow{2}{*}{ Province } & \multirow{2}{*}{$\begin{array}{c}\text { Number of } \\
\text { tourists }\end{array}$} & \multirow{2}{*}{$\begin{array}{c}\text { Average length } \\
\text { of stay (days) }\end{array}$} & $\begin{array}{c}\text { Average daily } \\
\text { expenditure } \\
\text { (Euros)* }\end{array}$ & \multicolumn{2}{|c|}{ Direct impact of tourism } \\
\cline { 5 - 6 } & & & 56 & $1,255,520,000$ & 10.4 \\
\hline Almeria & $2,360,000$ & 9.5 & 76 & $1,541,212,000$ & 12.7 \\
\hline Cadiz & $2,939,000$ & 6.9 & 64 & $374,170,000$ & 3.1 \\
\hline Cordoba & $1,008,000$ & 5.8 & 69 & $1,345,114,000$ & 11.1 \\
\hline Granada & $3,046,000$ & 6.4 & 52 & $407,888,000$ & 3.4 \\
\hline Huelva & $1,480,000$ & 5.3 & 54 & $5,509,188,000$ & 45.5 \\
\hline Malaga & $7,036,000$ & 14.5 & 92 & $1,419,155,000$ & 11.7 \\
\hline Seville & $2,488,000$ & 6.2 & 75 & $254,355,000$ & 2.1 \\
\hline Jaen & $1,094,000$ & 3.1 & 67 & $12,106,602,000$ & 100.0 \\
\hline Andalusia & $21,451,000$ & 9.9 & & 52 & \\
\hline
\end{tabular}

(*) Average daily expenditure has been updated based on the CPI, base 2011 (INE), for the period 20032012 in order to enable comparisons, avoiding the effect of inflation between the economic impact in 2003 and the economic impact in 2012.

Source: Authors' own processing based on the Andalusian Tourism Situation Survey (2003).

Table 5 Direct economic impact of tourism in Úbeda-Baeza (2003)

\begin{tabular}{|c|c|c|c|c|c|c|}
\hline Destination & $\begin{array}{l}\text { Number of } \\
\text { tourists }\end{array}$ & $\begin{array}{c}\text { Average } \\
\text { length of } \\
\text { stay (days) }\end{array}$ & $\begin{array}{l}\text { Average daily } \\
\text { expenditure } \\
\text { (Euros)* }^{*}\end{array}$ & \multicolumn{2}{|c|}{ CL (95\%) } & \multirow{2}{*}{$\begin{array}{c}\text { Direct impact of } \\
\text { tourism (Euros) }\end{array}$} \\
\hline Úbeda - Baeza & 102,000 & 1.56 & 75 & 72 & 76 & \\
\hline \multicolumn{7}{|c|}{$\begin{array}{l}\left.{ }^{\star}\right) \text { Average daily expenditure has been updated based on the CPI, base } 2011 \text { (INE), for the period 2003- } \\
2012 \text { in order to enable comparisons, avoiding the effect of inflation between the economic impact in } \\
2003 \text { and the economic impact in } 2012 \text {. }\end{array}$} \\
\hline
\end{tabular}

Source: Authors' own processing based on the Hotel Occupancy Survey (2003).

2012 in order to understand what happened during that decade and draw some conclusions on the basis of the results from this comparative analysis.

In addition, Table 6 presents the direct economic impact of tourism in Andalusia for the year 2012, including the disaggregated data required to calculate it for each of the provinces of Andalusia. 
Table 6 Direct economic impact of tourism in Andalusia (2012)

\begin{tabular}{|l|c|c|r|r|r|}
\hline \multirow{2}{*}{ Province } & \multirow{2}{*}{$\begin{array}{c}\text { Number of } \\
\text { tourists }\end{array}$} & \multirow{2}{*}{$\begin{array}{c}\text { Average length } \\
\text { of stay (days) }\end{array}$} & $\begin{array}{c}\text { Average daily } \\
\text { expenditure } \\
\text { (Euros) * }\end{array}$ & \multicolumn{2}{|c|}{ Direct impact of tourism } \\
\cline { 5 - 6 } & & & 44 & $763,699,000$ & 7.5 \\
\hline Almeria & $1,808,000$ & 9.6 & 72 & $1,743,379,000$ & 17.0 \\
\hline Cadiz & $3,186,000$ & 7.6 & 51 & $267,852,000$ & 2.6 \\
\hline Cordoba & $1,313,000$ & 4 & 61 & $1,130,025,000$ & 11.0 \\
\hline Granada & $3,250,000$ & 5.7 & 48 & $556,987,000$ & 5.4 \\
\hline Huelva & $1,507,000$ & 7.7 & 55 & $4,892,448,000$ & 47.8 \\
\hline Malaga & $7,232,000$ & 12.3 & 73 & $732,511,000$ & 7.2 \\
\hline Seville & $2,712,000$ & 3.7 & 97 & $140,417,000$ & 1.4 \\
\hline Jaen & 517,000 & 2.8 & 60 & $10,227,318,000$ & 100.0 \\
\hline Andalusia & $21,525,000$ & 9.4 & & &
\end{tabular}

Source: Authors' own processing based on the Andalusian Tourism Situation Survey (2012).

The greastest direct economic impact of tourism in 2012 was shown in the provinces of Malaga, due to the high number of tourists staying overnight and the average length of stay; Cadiz, because of its high number of visitors; and Seville, owing to tourists' average daily expenditure.

The direct economic impact of tourism in Úbeda and Baeza in 2012 is shown below (Table 7). In this regard, since the daily average expenditure for that year is not available, this data were estimated on the basis of the information collected by the survey conducted in September 2013.

Table 7 Direct economic impact of tourism in Úbeda-Baeza (2012)

\begin{tabular}{|c|c|c|c|c|c|c|}
\hline Destination & $\begin{array}{c}\text { Number of } \\
\text { tourists }\end{array}$ & $\begin{array}{c}\text { Average } \\
\text { length of } \\
\text { stay (days) }\end{array}$ & $\begin{array}{c}\text { Average daily } \\
\text { expenditure } \\
\text { (Euros) }^{*}\end{array}$ & \multicolumn{2}{|c|}{$\mathrm{CL}(95 \%)$} & $\begin{array}{c}\text { Direct impact of } \\
\text { tourism (Euros) }\end{array}$ \\
\hline Úbeda - Baeza & 109,000 & 1.59 & 197 & 195 & 199 & $34,142,000$ \\
\hline
\end{tabular}

Source: Authors' own processing based on the Hotel Occupancy Survey (2012).

The number of tourists visiting these two destinations increased in these ten years (going from 102,000 tourists in 2003 to 109,000 tourists in 2012). Although the average length of stay remained largely unchanged during this period (1.56 days in 2003, compared to 1.59 days in 2012), the average daily expenditure increased significantly, from 75 Euros in 2003 to 197 Euros in 2012 (moreover, the average daily expenditure here is much higher than in other provinces of Andalusia, which results in the whole province of Jaen having the highest average level of expenditure in Andalusia). This translates, 
eventually, into an increase by 22,208,000 Euros in the revenues of the destinations analysed over the last ten years.

This significant increase in tourist expenditure was mainly due to the consolidation of the image as the tourist destinations of Ubeda and Baeza, which allowed that these destinations attracted greater extent a type of tourists with high purchasing power (see Table 3), which performs a major expense at destination.

However, attracting tourists with high purchasing power does not guarantee, by itself, an increase of tourist spendings; but also requires an increase in the quantity and quality of tourism supply. In this regard, it should be noted that since the declaration of Ubeda and Baeza as World Heritage Site in 2003, these destinations have been involved in a major tourist development, resulting in new public and private initiatives, launch and diversification of supply existing (Sánchez-Rivero \& Pulido-Fernández, 2012), which has led to some interesting initiatives (creation of an upscale hotel supply, development of new eating establishments, development of new cultural itineraries, or enhancement of olive oil culture for additional income).

However, although it has expanded the range of tourism products that are part of the additional offer, which has led to the increased average daily expenditure, development of new tourism has not had a significant effect on the average stay. Thus, the structure of the visit is similar as it used to be ten years ago, although now the consumed tourism product (accommodation, or catering) is of higher quality and therefore involves higher spending tourists.

Therefore, this first approach indicates that, as a result of the designation of Úbeda and Baeza as World Heritage Sites, these cities has acquired an image as a tourism destination which has enabled a growth in tourist arrivals and, in particular, it has helped to attract the tourists who spend more money in the destination, which translates into the increased revenue for both cities.

\section{Conclusion}

The findings of the research carried out in this paper help support the initial hypothesis. Over the last decade, there has been an increase in the direct economic impact generated by tourism in these two destinations, amounting to approximately 22 million Euros (accordance with the calculation of confidence intervals, tourism increased their direct impact during the period analyzed between 21.6 and 23.0 million Euros), as a result, mainly of the growth in the average expenditure by tourists visiting Úbeda and Baeza, who now spend more than they did a decade ago.

Since the designation of Úbeda and Baeza as World Heritage Sites by UNESCO, tourism activities have grown in this territory, which has led to the development of new tourism infrastructure. This has enabled the diversification of the existing tourist offer by means of a wide range of resources that satisfy the new demands of tourists, which has, in turn, resulted in greater expenditure by tourists in the destination owing to the consumption of these new products that have emerged after the designation as World 
Heritage Sites of Úbeda and Baeza.

Therefore, it can be confirmed that the status of Úbeda and Baeza as World Heritage Sites, designated by UNESCO, has had a greater economic impact thanks to the expansion of tourism, mainly as a result of an increase in the average expenditure, and to a lesser extent, of an increase in the number of tourist arrivals. This is explained by the consolidation of the image as tourist destinations of Úbeda and Baeza, which have attracted a type of tourist that is characterised by high purchasing power, which has increased the average level of expenditure in the destination.

However, it must be remembered that tourism has an important impact on the cultural environment in which it develops. That is why this may be affected by the development of tourism demand. In this sense, although Ubeda and Baeza are currently well below the limit of its carrying capacity, managers of these destinations should consider this issue in the future development of the activity, as a number of negative impacts (noise pollution, degradation of heritage resources, an opportunity cost of tourism, or a loss of cultural identity.) may occur that endanger the tourism product which currently exists.

Thus, in line with the Strategy for Sustainable Tourism of Andalusia, the management objective of these cities is twofold: to create a tourism product of excellence (so as to increase spendings by tourists) and convert both cities in a unique sustainable tourist destination (reducing the negative impacts that may cause such activity). This requires to achieve a number of objectives which are to improve the current tourism, strengthening the competitiveness of business activities related to tourism and the maintenance and improvement of tourist areas of Ubeda-Baeza.

However, the empirical work that has been performed implies a number of limitations that must be indicated. Firstly, there was no information available on tourism expenditure for 2012. That is why it was necessary to design a survey, with the problems that entails; thus, given the limited time available, it was conducted at a particular time of the year (September 2013), even though, ideally, it should have been conducted throughout the year. For this reason, and because of the special relevance of seasonality in the tourism sector, which can even change tourists' preferences depending on when they visit the destination, it would have been advisable to conduct this survey during a longer period of time, and also to increase the number of participants in the survey in order to reduce the sampling error. Secondly, the average daily expenditure per tourist in Úbeda and Baeza that was used to quantify the direct economic impact of tourism in 2012 is obtained from the survey conducted in September 2013 because it was not possible to obtain these data from other different sources.

Finally, a set of proposals for the future that have emerged throughout this research work, and which initiate new and interesting lines of research, have been included. On the one hand, since tourism, due to its ability to stimulate other sectors of the economy, generates not only direct, but also indirect and induced impacts, a line of research is proposed that approaches to the study of the total economic impact generated by tourism in Úbeda and Baeza. On the other hand, it seems interesting to identify those factors determining expenditure by tourists in these destinations as some other authors in their research studies carried out in different destinations have shown. 


\section{References}

Barroso, M., \& Flores, D. (2006). La competitividad internacional de los destinos turísticos: Del enfoque macroeconómico al enfoque estratégico. Cuadernos de Turismo, 17, 7-24.

Bigné, E., Andreu, L., \& Font, X. (2000). Marketing de destinos turísticos. Análisis y estrategias de desarrollo. Barcelona: Esic Editorial.

Brida, J. G., \& Scuderi, R. (2013). Determinants of tourist expenditure: a review of microeconometric models. Tourism Management Perspective, 6, 28-40. DOI: 10.1016/j.tmp.2012.10.006

Calderón, S. (2009). Conceptos de patrimonio, atractivo turístico y recurso turístico. Retrieved from http:/ / estudiosdelturismo.blogspot.com.es/2009/05/conceptos-de-patrimonio-atractivo.html

Cárdenas, P. J. (2012). Crecimiento turístico versus Desarrollo Económico. Revista de Economía Mundial, 32, 73-112. DOI: 10.1016/j.tmp.2012.10.006

Crompton, J. L. (1979). An Assessment of the Image of Mexico as a Vacation Destination and the Influence of Geographical Upon That Image. Journal of Travel Research, 17, 4 18-23. DOI: $10.1177 / 004728757901700404$

Ditcher, E. (1985). "What is in an Image?", Journal of Consumer Marketing 2: 39-52.

Echtner, C. M., \& Ritchie, B. J. R. (1991). The Meaning and Measurement of Destination Image. The Journal of Tourism Studies, 2(2), 2-12. DOI: 10.1177/004728759303100402.

Frechtling, D. C. (1994). Assessing the economic impact of travel and tourism. Introduction to travel economic impact estimation”. In B. J. R. Ritchie, \& C. R. Goeldner (Eds.). Travel, Tourism, and Hospitality Research. A handbook for managers and researchers (pp. 359-365). New York: John Wiley \& Sons, Inc.

Fredman, P. (2008). Determinants of visitor expenditures in mountain tourism. Tourism Economics, 14(2), 297-311. DOI: 10.5367/000000008784460418

García-Sánchez, A., Fernández-Rubio, E., \& Collado, M. D. (2013). Daily expenses of foreign tourists, length of stay and activities: Evidence from Spain. Tourism Economics, 19(3), 613-630. DOI: $10.5367 /$ te. 2013.0218

Instituto de Estadística y Cartografía de Andalucía. (2003, 2012). Sistema de Información Multiterritorial de Andalucia (SIMA). Retrieved from http://www.juntadeandalucia.es/institutodeestadisticaycartografia/sima/index2.htm

Instituto de Estadística y Cartografía de Andalucía. (2003, 2012). Encuesta de Coyuntura Turística de Andalucia. Retrieved from http://www.juntadeandalucia.es/institutodeestadisticaycartografia/ turismo/index.htm

Instituto Nacional de Estadística. (2003). Encuesta de Ocupación Hotelera. Retrieved from http:// www.ine.es $/ \mathrm{jaxi} /$ menu.do?L=0\&type=pcaxis\&path=\%2Ft11/e162eoh\&file=inebase

Kim, S. S., Han, H., \& Chon, K. (2008). Estimation of the determinants of expenditure by festival visitors. Tourism Analysis, 13(4), 387-401. DOI: 10.5367/000000008784460418

King, R., \& Woodside, A. (2001). An Updated Model of Travel and Tourism Purchase- Consumption System. Journal of Travel and Tourism Marketing, 10(1), 3-27. DOI: 10.1300/J073v10n01_02

Laesser, C., \& Crouch, G. (2006). Segmenting Markets by Travel Expenditure Patterns: The Case of International Visitors to Australia. Journal of Travel Research, 44, 397-406. DOI: $10.1177 / 0047287505282952$

Leask, A. (2006). World Heritage Site Designation. In A. Leask, \& A. Fyall (Eds.). Managing World Heritage Sites (pp. 5-19). Oxford: Oxford University Press.

Martínez, F. (2003). Turismo rural: características de la actividad e impacto económico en Galicia. Tesis doctoral. Universidad de Santiago de Compostela. 
Mazón, T., \& Aledo, A. (2005). El Turismo residencial y cambio social. Nuevas perspectivas teóricas y empiricas. Alicante: Aguaclara.

Mok, C., \& Iverson, T. (2000). Expenditure-based segmentation: Taiwanese tourists to Guam. Tourism Management, 21, 299-305. DOI: 10.1016/S0261-5177(99)00060-6

Oxenfeldt, A. R. (1974). Developing a Favorable Price-Quality Image. Journal of Retailing, 50(4), 8-14. DOI: $10.1177 / 0047287512465959$

Pawlowska, E., \& Martínez, F. (2009). Una aproximación al impacto económico directo del turismo académico: el caso de los intercambios Erasmus en la Universidad de Santiago de Compostela. Revista Galega de Economía, 18(2), 91-110.

Poria, Y., Reichel, A., \& Cohen, R. (2011). World Heritage Site- Is it an effective brand name? A case of a religious heritage site. Journal of Travel Research, 50(5), 482-495. DOI: $10.1177 / 0047287510379158$

Pulido-Fernández, J. I. (2013). Gestión de la cadena de valor del destino turístico. In J.I. PulidoFernández \& Y. López-Sánchez, Y. (Ed.). Gestión estratégica sostenible de destinos turísticos (pp. 521577). Seville: Universidad Internacional de Andalucía. DOI: 10.1177/0047287510379158

Sánchez-Rivero, M., \& Pulido-Fernández, J. I. (2012). Testing Heterogeneous Image in Cultural/ Non-cultural Tourism Markets: a Latent Model Approach. International Journal of Tourism Research, 14(3), 250-268. DOI: 10.1002/jtr.850

Stynes, D. J. (1999). Approaches to estimating the economic impacts of tourism; some examples. Retrieved from https://www.msu.edu/course/prr/840/econimpact/pdf/ecimpvol2.pdf

Thrane, C., \& Farstad, E. (2011). Domestic tourism expenditures: The non-linear effects of length of stay and travel party size. Tourism management, 32, 46-52. DOI: 10.1016/j.tourman.2009.11.002

Torres, E. (2003). El turismo residenciado y sus efectos en los destinos turísticos. Estudios Turísticos, $155,45-70$.

Venturini, E. J. (2010). Los itinerarios culturales como base para propuesta de desarrollo turístico sustentable. Retrieved from http://www.revistaamericapatrimonio.org/art_5_4.pdf

Wang, Y. (2007). Customized Authenticity Begins at Home. Annals of Tourism Research, 34(3), 789804. DOI: $10.1016 /$ j.annals.2007.03.008

Wikemedia Commons (2014). Comarca de La Loma. Retrieved from http://commons.wikimedia. org/wiki/File:Comarca_de_La_Loma.svg WikimediaWinter, Y. (2007). Rethinking Tourism in Asia. Annals of Tourism Research, 34(1), 27-44. DOI: 10.1016/j.annals.2006.06.004

Woodside, A., \& Dubelaar, C. (2002). A General Theory of Tourism Consumption Systems: A conceptual Framework and an Empirical Exploration. Journal of Travel Research, 41(2), 120-132. DOI: $10.1177 / 004728702237412$

World Tourism Organization - UNWTO. (1998). Guía para administradores locales: desarrollo turistico sostenible. Madrid: UNWTO.

Wu, L., Zhang, J., \& Fujiwara, A. (2011). Representing tourist's time use behavior based on a multiple discrete continuous extreme value model. Journal of the Eastern Asia Society for Transportation Studies, 9, 796-809. 